\title{
ANALISIS PENGARUH FINANCING TO DEPOSIT RATIO (FDR) TERHADAP PENEMPATAN DANA PADA SBIS BANK SYARIAH DI INDONESIA')
}

\author{
Supriono \\ Mahasiswa Program Studi S1 Ekonomi Islam-Fakultas Ekonomi dan Bisnis-Universitas Airlangga \\ Email :ucup.suprio25@gmail.com
}

Sri Herianingrum

Departemen Ekonomi Syariah-Fakultas Ekonomi dan Bisnis-Universitas Airlangga

Email :Sriheria@yahoo.co.id

\begin{abstract}
:
This study aimed to analyze the influence of Financing to Deposit Ratio (FDR) and to islamic banking fund placement in Islamic Certificate of Bank Indonesia Sharia (SBIS) in the period January 2009-December 2015. The research approach used is a quantitative technique of linear regression analysis. The dependent variable used is the placement of funds in SBIS, while the independent variables, Financing to Deposit Ratio (FDR). Determination of the number of samples using a non probability sampling methods saturated samples, the entire population sampled. The data used is secondary data. The regresion test results stating that the Financing to Deposit Ratio (FDR) significantly affects the placement of funds of islamic bank at SBIS in the period January 2009-December 2015.
\end{abstract}

Keywords: FDR, SBIS Rate of return SBIS, Islamic Banking.

\section{PENDAHULUAN}

\section{Latar Belakang}

Pada perekonomian selalu terjadi fenomena-fenomena dari ekspansi sampai resesi, munculnya resesi salah satunya disebabkan oleh terlalu banyaknya jumlah vang yang beredar sehingga menyebabkan inflasi. Untuk menjaga stabilitas perekonomian, Bank Indonesia sebagai bank sentralnya Indonesia bertugas penuh melalui kebijakan moneter dalam mengendalikan jumlah vang beredar yang salah satunya melalui Operasi Pasar Terbuka (OPT). Kebijakan moneter merupakan otoritas moneter dalam bentuk pengendalian besaran moneter untuk mencapai perkembangan kegiatan perekonomian yang diinginkan (Warjiyo dan Solikin,2003:2). Besaran moneter (monetary aggregates) yang dimaksud dapat berupa Jumlah Uang Beredar (JUB), vang primer atau kredit perbankan. Pemegang otoritas moneter tertinggi di Indonesia adalah Bank Indonesia yang memiliki tujuan mencapai dan memelihara kestabilan rupiah, sebagaimana yang tertulis dalam UU No.3 Tahun 2004 tentang Bank Indonesia pasal 7 ayat 1. Kestabilan nilai rupiah yang dimaksud dalam undang-undang tersebut adalah kestabilan nilai rupiah terhadap harga barang dan jasa yang tercermin pada inflasi. Serta terhadap mata vang Negara lain yang tercermin pada nilai tukar rupiah (kurs) Operasi Pasar Terbuka (OPT) adalah kegiatan jual beli surat-surat berharga oleh bank sentral (Aulia Pohan,2008:33). Instrumen ini diwujudkan dengan penerbitan Sertifikat Bank

1) Jurnal ini merupakan bagian dari skripsi yang ditulis oleh Supriono, NIM: 041211432007, yang diuji pada tanggal 15 agustus 2016 
Supriono, et al/Jurnal Ekonomi Syariah Teori dan Terapan Vol. 4 No. 7 Juli 2017: 531-546; ANALISIS PENGARUH FINANCING TO DEPOSIT RATIO (FDR) TERHADAP PENEMPATAN DANA PADA SBIS BANK SYARIAH DI INDONESIA

Indonesia (SBI) untuk bank konvensional dan Sertifikat Bank Indonesia Syariah (SBIS) untuk bank syariah. Pada instrumen ini hanya melibatkan dua pihak yaitu Bank Indonesia (sebagai penjual) dan perbankan (sebagai pembeli). Penempatan dana oleh perbankan pada Bank Indonesia melalui OPT akan berpengaruh pada likuiditas perbankan yang kemudian akan berpengaruh juga pada kemampuan perbankan memberikan pinjaman atau pembiayayaan. Dalam rangka menjaga likuiditasnya bank perlu menanamkan dananya pada surat-surat berharga. Sebagaimana Wibowo dan Widodo (2005:29) mengatakan cadangan sekunder untuk memenuhi kebutuhan likuiditasnya berjangka waktu kurang dari satu tahun sekaligus memperoleh laba. Bentuknya berupa Sertifikat Bank Indonesia (SBI), Surat Berharga Pasar Uang (SBPU), Sertifikat Deposito, dan commercial paper. Besar kecilnya kemampuan perbankan dalam memberikan pinjaman juga didasarkan pada likuiditas bank yang bersangkutan. Pembiayaan yang dilakukan oleh bank maka secara langsung juga berpengaruh pada sektor riil. Sejak dikeluarkannya UU Bank Indonesia No.23 tahun 1999 yang kemudian diubah dalam UU No. 3 tahun 2004 yang menyebutkan bahwa Bank Indonesia diberi amanah sebagai otoritas moneter ganda yang dapat menjalankan kebijakan moneter konvensional maupun syariah. Berdasarkan UU Bank Indonesia tersebut maka di Indonesia ada dua jalur dalam transmisi kebijakan moneter yaitu jalur bagi hasil sebagai komplemen dari perbankan syariah sebagai komplemen dari jalur kredit perbankan.

$$
\text { Berdasarkan Undang-Undang }
$$
Republik Indonesia nomor 23 Tahun 1999 tersebut maka pengendalian moneter dapat dilaksanakan dengan dua prinsip. Perbankan syariah menggunakan sistem tanpa bunga (free interest rate system), sedangkan perbankan konvensional tetap menggunakan sistem berbasis bunga (base interest rate system). Menurut beberapa pandangan ulama bunga diqiyaskan dengan riba. Larangan penggunaan riba dalam islam terdapat dalam Firman Allah Qur'an surat alBaqarah ayat 275 sebagai berikut:

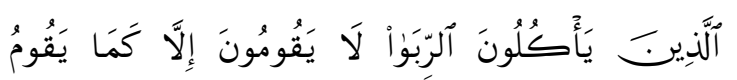

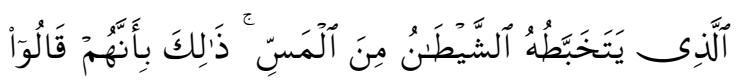

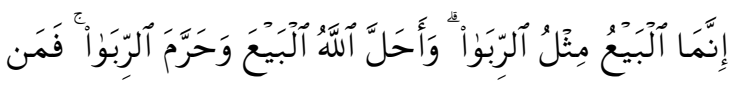

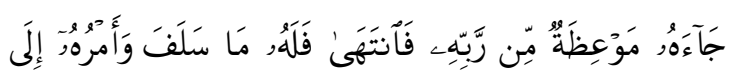

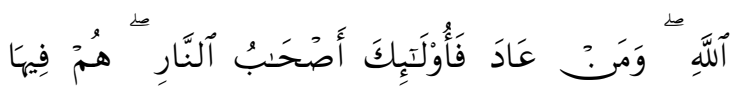

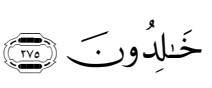

Artinya : "Orang-orang yang Makan (mengambil) riba tidak dapat berdiri melainkan seperti berdirinya orang yang kemasukan syaitan lantaran (tekanan) penyakit gila. Keadaan mereka yang demikian itu, adalah disebabkan mereka berkata (berpendapat), Sesungguhnya jual beli itu sama dengan riba, Padahal Allah telah menghalalkan jual beli dan mengharamkan riba. orang-orang yang telah sampai kepadanya larangan dari Tuhannya, lalu terus berhenti (dari mengambil riba), Maka baginya apa yang telah diambilnya dahulu (sebelum datang larangan); dan urusannya (terserah) kepada Allah. orang yang kembali (mengambil riba), Maka orang itu 
adalah penghuni-penghuni neraka; mereka kekal di dalamnya.(QS Al Baqarah:275 (Depag Rl,2005:86).

Peraturan syariah tentang larangan mengambil riba, menghindari kegiatan yang bersifat spekulatif, kewajiban mempertimbangkan masalah moralitas, kehalalan dan kemashlahatan bagi masyarakat mengakibatkan bank-bank syariah memiliki keterbatasan dalam memilih investasi. Sementara itu dengan jelas islam mengharamkan peminjaman modal dengan cara menarik bunga (Hidayat,2010:223). Dari kendala inilah peran lembaga intermediasi keuangan yang sesuai dengan hukum islam sangat diperlukan, Muhammad mengatakan bahwa salah satu peran perbankan syariah adalah memperkuat basis permodalan.

Penggunaan sistem bunga yang selama ini dijalankan tidak mampu menyelesaikan masalah perekonomian yang dihadapi semua bangsa yang telah berlangsung sekian lama. Sumitro (2004:14) mengatakan sistem perbankan yang menerapkan bunga menimbulkan laju inflasi semakin tinggi, karena ada kecenderungan bank-bank untuk memberikan kredit secara berlebihlebihan. Penyebabnya adalah cara penciptaan vang baru tersebut dalam suatu sistem berdasarkan bunga tergantung pasar operasi-operasi peminjaman bank-bank komersial.

Untuk mendukung kinerja perbankan syariah , maka bank Indonesia sebagai regulator juga mengeluarkan instrumen moneter berdasarkan prinsip syariah. Selain untuk mengendalikan jumlah vang yang beredar instrumen moneter juga berfungsi sebagai wadah penempatan dana bank syariah yang mengalami kelebihan likuiditas. Bank Indonesia mengeluarkan kebijakan moneter berbasis syariah melalui Operasi Pasar Terbuka (OPT) dengan menerbitkan Sertifikat Bank Indonesia Syariah (SBIS). Sebelumnya Bank Indonesia juga menerbitkan instrument moneter syariah berupa Sertifikat Wadiah Bank Indonesia (SWBI) sebagaimana tercantum dalam Fatwa DSN-MUI Nomor 36/DSN-MUI/X/2002 tentang SWBI disebutkan bahwa SWBI dapat dimanfaatkan oleh bank syariah untuk mengatasi likuiditasnya. Akan tetapi, SWBI tersebut dianggap belum terlalu efektif, sehingga Bank Indonesia menerbitkan Sertifikat Bank Indonesia Syariah (SBIS) sebagai pengganti SWBI.

Sepuluh tahun Sertifikat Wadiah Bank Indonesia (SWBI) digunakan sebagai instrumen oleh perbankan syariah dalam menempatkan dana pada Bank Indonesia. Sertifikat pertama yang dikeluarkan oleh Bank Indonesia adalah Sertifikat Wadiah Bank Indonesia (SWBI) dengan menggunakan akad wadi'ah berdasarkan Undang-undang nomor 10 Tahun 1998 Perbankan Syaruah. Namun, pada tahun 2008 Bank Indonesia mengeluarkan Peraturan Bank Indonesia Nomor 10/11/PBI/2008 yaitu mengganti Sertifikat Wadiah Bank Indonesia menjadi Seritifikat Bank Indonesia Syariah (SBIS) yang berakad Ju'alah (Gulo 2014:2). 
Supriono, et al/Jurnal Ekonomi Syariah Teori dan Terapan Vol. 4 No. 7 Juli 2017: 531-546; ANALISIS PENGARUH FINANCING TO DEPOSIT RATIO (FDR) TERHADAP PENEMPATAN DANA PADA SBIS BANK SYARIAH DI INDONESIA

Berikut adalah rangkuman penempatan dana perbankan syariah pada SBIS:

Tabel 1.

Rata-rata tahunan Penempatan dana pada Bank Indonesia-Bank Umum Syariah dan Unit Usaha Syariah (dalam triliun)

\begin{tabular}{|c|c|c|c|c|c|c|c|}
\hline Indikalor & 2009 & 2010 & 2011 & 2012 & 2013 & 2014 & 2015 \\
\hline Giro & & & & & & & \\
\hline Wodiah & 2.694 & 4.176 & 5.967 & 7.862 & 10.763 & 11,101 & 11.18 \\
\hline SIVB//SBS & 3.076 & 5.408 & 9.244 & 4.993 & 6.699 & 6.359 & 8.065 \\
\hline Lainnyo & 4.623 & 6.809 & 11.915 & 13.86 & 15.075 & 15.197 & 13.617 \\
\hline Total & 10.39 & 16.393 & 27.127 & 26.71 & 32.537 & 33.657 & 32862 \\
\hline
\end{tabular}

Sumber: Statistik Perbankan Syariah (diolah)

Berdasarkan Tabel 1.1 diatas volume SBIS mengalami peningkatan yang signifikan dari tahun 2009 sampai tahun 2011 yakni 3,076 triliun sampai 9,24 triliun, akan tetapi mengalami penurunan pada tahun 2012 yakni 4,993 triliun kemudian mengalami kenaikan dari tahun 2013 sampai tahun 2015 yakni 6,699 sampai 8.065 triliun. Peningkatan volume SBIS sangat signifikan di tiga tahun pertama dalam penelitian ini, padahal secara komposisi jumlah bank syariah lebih banyak di tahun terakhir penelitian ini yakni tahun 2013. Bank Syariah pada akhir tahun 2013 mengalami peningkatan dengan terbentuknya 12 Bank Umum Syariah dengan 2.174 jumlah kantor dan 22 Unit Usaha Syariah dengan 397 kantor tentunya terjadi peningkatan dalam jumlah Dana Pihak Ketiga (DPK) (Statitik Perbankan Syariah Juni 2015). Perbankan syariah memang mengalami penurunan Unit Usaha Syariah dan Jumlah kantornya tetapi dengan peningkatan Bank Umum
Syariah dan juga jumlah kantornya yang jauh lebih besar dari pada tahun sebelumnya, hal ini menunjukan bahwa perbankan syariah sangat diminati di Indonesia.

Sebagaimana fungsi utama bank syariah sebagai lembaga intermediasi dijalankan dengan alokasi pembiayaan (financing) yaitu memberikan fasilitas penyediaan dana untuk memenuhi kebutuhan pihak-pihak yang merupakan deficit unit (Arifin,2006:200). Selain untuk pembiayaan, bank syariah juga dapat mengalokasikan dananya untuk fungsi investasi pada surat-surat berharga (Muhammad, 2005:56). Penempatan dana perbankan syariah pada SBIS yang dilakukan oleh pihak perbankan syariah jika bank mengalami kesulitan dalam melakukan pembiayaan. Kemampuan perbankan syariah dalam melakukan pembiayaan dapat dilihat dari nilai FDR perbankan syariah. Semakin rendah FDR mengindikasikan bahwa semakin rendah kemampuan bank syariah dalam menyalurkan dananya pada pembiayaan. Ketika FDR perbankan syariah rendah akan berakibat meningkatnya likuiditas bank dalam hal inii maka ada dua pilihan yang bisa diambil oleh manajemen bank yaitu menahan dananya tetap di bank dengan konsekuensi dana tersebut akan menganggur dan mengurangi pendapatan rata-rata bank atau memilih menempatkan dananya pada SBIS ataU instrument lainnya. Pemilihan penempatan dana di SBIS pastinya 
Supriono, et al/Jurnal Ekonomi Syariah Teori dan Terapan Vol. 4 No. 7 Juli 2017: 531-546; ANALISIS PENGARUH FINANCING TO DEPOSIT RATIO (FDR) TERHADAP PENEMPATAN DANA PADA SBIS BANK SYARIAH DI INDONESIA

didasarkan pada pertimbanganpertimbangan dengan memperhatikan lima hal yaitu pendapatan yang baik (good return), risiko yang rendah (low risk), mudah dicairkan (redeemable), sederhana (simple), dan fleksibel (Arifin. 2005 : 173). Keberadaan SBIS sebagai instrument moneter dan sekaligus instrumen untuk menjaga likuiditas perbankan syariah sangatlah penting.

Berdasarkan uraian di atas, rumusan masalah yang ingin diajukan dalam penelitian ini adalah apakah Financing to Deposit Ratio (FDR berpengaruh signifikan terhadap penempatan dana pada SBIS bank syariah di Indonesia.

\section{LANDASAN TEORI DAN PENGEMBANGAN HIPOTESIS}

Menurut Muhammad (2005:17) menyatakan bahwa setiap penyaluran pembiayaan adalah pendanaan yang dikeluarkan untuk mendukung investasi yang direncanakan. Menurut Remi (1999:177) dalam Suhartatik (2014:1178) FDR merupakan perbandingan antara pembiayaan yang diberikan oleh bank dengan dana pihak ketiga yang berhasil dikerahkan oleh bank. Financing to Deposit Ratio (FDR) pada perbankan konvensional disebut dengan Loan to Deposit Ratio (LDR). LDR adalah rasio antara seluruh jumlah kredit yang diberikan bank dengan dana yang diterima oleh bank (Dendawijaya, 2005:1 18). Dalam perbankan syariah tidak dikenal istilah kredit (loan) namun pembiayaan atau financing (Antonio,2001:70). Pada umumnya konsep yang sama ditunjukan pada bank syariah dalam mengukur likuisitas yaitu dengan Financing to Deposit Ratio (FDR). Financing to Deposit Ratio (FDR) adalah seberapa besar Dana Pihak Ketiga (DPK) bank syariah dilepaskan untuk pembiayaan (Muhammad, 2009:265). Financing to Deposit Ratio (FDR) merupakan rasio yang digunakan untuk mengukur likuiditas suatu bank dalam membayar kembali penarikan dan yang dilakukan deposan dengan mengandalkan pembiayaan yang diberikan sebagai sumber likuiditasnya, yaitu dengan cara membagi jumlah pembiayaan diberikan oleh bank terhadap jumlah Dana Pihak Ketiga (DPK) (Suryani,2011:59).

Financing to Deposit Ratio yang sekanjutnya disingkat FDR adalah rasio pembiayaan yang diberikan kepada pihak ketiga dalam rupiah dan valuta, tidak termasuk pembiayaan pada bank lain, terhadap dana pihak ketiga yang mencakup giro, tabungan, deposito, dalam rupiah dan valuta asing, tidak termasuk antar bank (Ginting dkk,2013:74). Pada cetak biru perbankan syariah yang diterbitkan Bank Indonesia tahun 2002, FDR dianalogikan dengan Loan to Deposit Ratio (LDR) pada bank konvensional. Berikut adalah formula penghitungan Financing to Deposit Ratio: $\frac{\text { Jumlah Pembiayaan yang Diberikan }}{\text { Total Dana Pihak Ketiga }} \times 100 \%$

Sumber: Rivai dan Arifin (2010:559)

Semakin tinggi rasio tersebut memberikan indikasi rendahnya kemampuan likuiditas 
Supriono, et al/Jurnal Ekonomi Syariah Teori dan Terapan Vol. 4 No. 7 Juli 2017: 531-546; ANALISIS PENGARUH FINANCING TO DEPOSIT RATIO (FDR) TERHADAP PENEMPATAN DANA PADA SBIS BANK SYARIAH DI INDONESIA

bank yang bersangkutan (Rivai dan arifin,2010:560). Hal ini disebabkan karena jumlah dana yang digunakan untuk memberikan pembiayaan semakin besar sehingga akan semakin sedikit dana likuid dan resiko tidak terpenuhinya kemampuan membayar nasabah yang menarik dananya melebihi likuiditas bank. Sehingga sangat diperlukan bank syariah untuk menempatkan dananya pada instrumen lain yang lebih likuid. Kemampuan bank dalam memenuhi penarikan dana oleh deposan sangat penting untuk menjaga kepercayaan nasabah pada bank yang bersangkutan.

Sertifikat Bank Indonesia Syariah adalah surat berharga berdasarkan prinsip syariah berjangka waktu pendek dalam mata uang rupiah yang diterbitkan oleh Bank Indonesia (soemitra, 2009:213). SBIS diterbitkan oleh bank Indonesia sebagai salah satu instrumen Operasi Pasar Terbuka (OPT) dalam rangka pengendalian moneter yang dilakukan berdasarkan prinsip syariah (Ginting dkk, 2013:112).

SBIS yang diterbitkan oleh bank Indonesia menggunakan akad ju'alah. Akad ju'alah adalah janji atau komitmen (iltizam) untuk memberikan imbalan tertentu ('iwadh/ju'l) atas pencapaian hasil (natijah) yang ditentukan dari suatu pekerjaan (Ginting dkk, 2013:112) bank syariah hanya boleh/dapat menempatkan kelebihan likuiditasnya pada SBIS ju'alah sepanjang belum dapat menyalurkannya pada sektor riil (DSN, 2007:5).
Ju'alah adalah suatu kontrak dimana pihak pertama menjanjikan imbalan tertentu kepada pihak kedua atas pelaksanaan suatu tugas atau palayanan yang dilakukan oleh pihak kedua untuk kepentingan pihak pertama (Arifin, 2009:36). Instrumen ini menjadi masukan yang positif bagi perbankan syariah. Pasalnya, sebelum diterbitkannya SBIS ini sebelumnya menggunakan Sertifikat Wadiah Bank Indonesia (SWBI) dimana jika dibandingkan dengan SBI konvensional memiliki perbedaan bonus atau return yang sangat berbeda. Untuk itu bank Indonesia menerbitkan SBIS sebagai pengganti SWBI setelah mendapat izin dari Dewan Syariah Nasional (DSN). Dalam peraturan Bank Indonesia SBI Syariah diterbitkan melalui mekanisme lelang. Pihak yang berhak mengikuti lelang adalah Bank Umum Syariah (BUS) dan Unit Usaha Syariah (UUS) baru dapat mengikuti lelang SBIS jika memenuhi persyaratan Financial to Deposit Ratio (FDR) yang telah ditetapkan oleh bank Indonesia sebagaimana terdapat pada Pasal 7 ayat (1) : BUS dan UUS dapat memiliki SBIS melalui penjualan pembelian SBIS secara langsung atau melalui perusahaan pialang pasar vang rupiah dan valuta asing. Hapsari (2013:51) menyatakan:

"Dilihat dari hukum islam, penerbitan SBIS merupakan bagian dari kegiatan muamalah yang pelaksanaannya harus memenuhi nilai-nilai islam yang didasarkan pada sumber hukm yang utama yaitu Al-quran dan AL-hadits" Prinsip bermuamalah yang melandasi munculnya instrument SBIS 
dapat dijelaskan salah satunya dengan firman Allah dalam surat An-nisa ayat 29 di bawah ini:

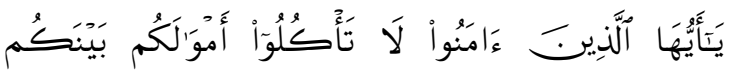

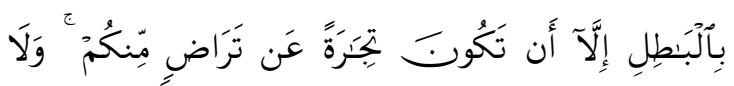

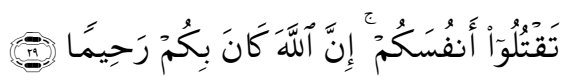

"Hai orang-orang yang beriman, janganlah kamu saling memakan harta sesamamu dengan jalan yang batil, kecuali dengan jalan perniagaan yang Berlaku dengan suka sama-suka di antara kamu. dan janganlah kamu membunuh dirimu ; Sesungguhnya Allah adalah Maha Penyayang kepadamu." (Q.S An-Nisa:29) (Depag Rl,2005:153).

Ayat diatas menyatakan bahwa islam memperbolehkan umat muslim untuk bermuamalah selama kegiatan tersebut dilandasi atas dasar sukarela dan tidak dilakukan dengan cara yang batil. Hal itu tidak hanya berlaku bagi umat muslim secara pribadi maupun lembaga, tetapi juga dalam lingkungan Negara khususnya dalam lingkup moneter.

Berdasarkan Peraturan Bank Indonesia Nomor 10/11/PBI/2008, SBIS diterbitkan dengan menggunakan akad ju'alah. Ju'alah adalah jenis akad atas manfaat sesuatu yang diduga akan diperolehnya. Secara etimologis, Ju'alah berarti upah atau hadiah yang diberikan kepada seseorang karena orang tersebut telah melaksanakan suatu pekerjaan. Sedangkan secara terminologis, berarti suatu tanggungjawab dalam bentuk janji memberikan imbalan upah tertentu secara sukarela terhadap orang yang berhasil melakukan perbuatan atau memberikan jasa yang belum pasti dapat dilaksanakan atau dihasilkan sesuai dengan yang diharapkan. Adapaun dasar hukum ju'alah adalah seperti yang tertera dalam surat Yusuf ayat 72 sebagai berikut:

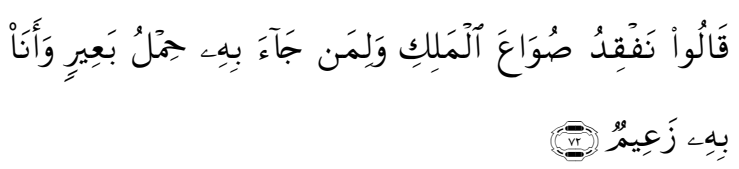
"Penyeru-penyeru itu berkata: "Kami kehilangan piala Raja, dan siapa yang dapat mengembalikannya akan memperoleh bahan makanan (seberat) beban unta, dan aku menjamin terhadapnya".(Q.S Yusuf:72) (Depag $\mathrm{Rl}, 2005)$.

Ayat diatas dapat dijasikan landasan penerapan akad ju'alah dalam instrumen SBIS dengan interpretasi ayat sebagai berikut: penguasa di dalam kisah surat yusuf ayat 72 berjanji untuk memberikan sejumlah imbalan kepada siapa saja yang mampu memenuhi tugas penguasa, yaitu mengembalikan piala raja yang hilang. Hal ini sama dengan pihak Bank Indonesia yang berperan sebagai pemegang otoritas moneter menjanjikan sejumlah imbalan kepada bank stariah manapun yang mampu memenuhi tugas dalam hal pengendalian moneter melalui penyerapan likuiditas dengan cara menempatkan sebagaian dana bank syariah kedalam instrument SBIS.

Hubungan Antara FDR Terhadap Penempatan Dana Pada SBIS. Pembiayaan merupakan fungsi bank dalam menjalankan fungsi penggunaan dana (Muhammad,2005:56). Kegiatan pembiayaan (financing) merupakan salah satu tugas pokok bank, yaitu pemberian fasilitas penyediaan dana untuk 
memenuhi kebutuhan pihak-pihak yang merupakan deficit unit (Arifin,2006:200).

Namun dalam setiap keputusan penggunaan dana untuk pembiayaan, meskipun menguntungkan, tetap mengandung suatu resiko bisnis (Muhammad,2005:220). Oleh sebab itu dalam pelemparan dana harus dipertimbangkan berbagai resiko diantaranya adalah resiko likuiditas. Pembiayaan yang tinggi memberikan dampak resiko likuiditas yang lebih tinggi, ini dapat dilihat dengan rasio yang ditunjukan oleh FDR, semakin tinggi nilai FDR maka semakin tinggi resiko likuiditas yang mengancam bank syariah (A'la, 2014:595).

Terjadinya resiko likuiditas yang sewaktu-waktu dapat menimpa bank syariah, maka bank syariah membutuhkan instrumen likuiditas yang likuid, yang bertujuan untuk memenuhi kebutuhan likuiditas perbankan syariah. Salah satu instrumen yang diciptakan oleh Bank Indonesia adalah Sertifikat Bank Indonesia Syariah (SBIS) yang dianggap salah satu penempatan likuiditas yang aman dan likuid.

Porsi terbesar kedua dari fungsi penggunaan dana bank adalah investasi pada surat-surat berharga (Arifin,2006:53). Hal ini mengindikasikan adanya hubungan terbalik antara pembiayan dengan penempatan dana pada SBIS. Semakin banyak dana yang dialokasikan pada pembiayaan maka akan mengurangi jumlah dana yang ditempatkan pada investasi di SBIS begitu pula sebaliknya, berkurangnya jumlah dana yang dialokasikan pada pembiayaan akan meningkatnya jumlah dana yang ditempatkan pada investasi di SBIS, hall tersebut juga berhubungan dengan fungsi manajemen likuiditas yang harus dikelola oleh bank syariah. Pada penelitian yang dilakukan oleh A'la (2014:592) menyatakan bahwa FDR berpengaruh negatif signifikan pada jumlah dana yang ditempatkan pada SBIS.

Berdasarkan rumusan masalah, landasan teori dan penelitian sebelumnya maka hipotesis dapat dirumuskan sebagai berikut:

$\mathrm{H1}$ : Finacing To Deposit Ratio (FDR) berpengaruh signifikan terhadap Penempatan dana pada Sertifikat Bank Indonesia Syariah (SBIS).

Model analisis yang digunakan dalam penelitian ini adalah sebagai berikut:

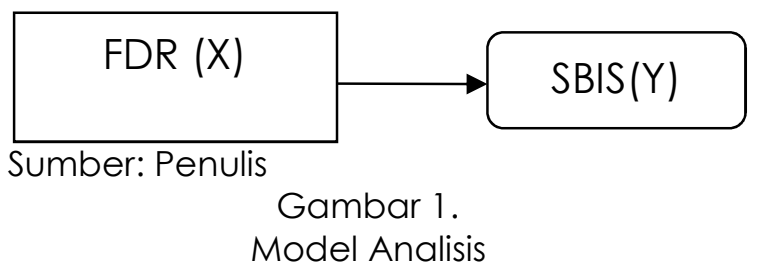

\section{METODE PENELITIAN}

\section{Pendekatan Penelitian}

Pendekatan penelitian yang digunakan dalam penelitian ini adalah pendekatan penelitian kuantitatif. Anshori dan Iswati (2009:13), mendefinisikan bahwa "Penelitian kuantitatif adalah suatu metode penelitian yang mengkuantitatifkan data dan 
Supriono, et al/Jurnal Ekonomi Syariah Teori dan Terapan Vol. 4 No. 7 Juli 2017: 531-546; ANALISIS PENGARUH FINANCING TO DEPOSIT RATIO (FDR) TERHADAP PENEMPATAN DANA PADA SBIS BANK SYARIAH DI INDONESIA

menerapkan satu bentuk analisis untuk menerima atau menolak hipotesis".

\section{Identifikasi variabel}

Menurut Indriantoro dan Supomo (2002:61) variabel merupakan representasi dari anstraksi fenomena-fenomena kehidupan nyata diamati dan dapat diukur dengan berbagai macam nilai berupa angka atau atribut yang menggunakan ukuran skala dalam suatu kisaran nilai.

Berdasarkan rumusan masalah yang telah dijelaskan, maka terdapat dua jenis variabel yang digunakan dalam penelitian ini yaitu Variabel Independen Financing To Deposit Ratio (FDR) (X) dan variabel dependen Sertifikat Bank Indonesia Syariah (SBIS) periode Januari 2009 sampai dengan Desember 2015 (Y).

\section{Definisi Operasional}

Definisi operasional adalah suatu definisi yang diberikan pada suatu variabel atau konstrak dengan cara memberikan arti, atau menspesifikasikan kegiatan, ataupun memberikan suatu operasional yang diperlukan untuk mengukur konstrak atau variabel tersebut (Nazir,2005:126). Definisi operasional menyatakan bagaimana operasi atau kegiatan yang harus dilakukan untuk memperoleh data atau indikator yang menunjukan konsep yang dimaksud (Soehartono, 1999:29). Dalam penelitian ini terdapat dua variabel utama yaitu:

1. Variabel Independen
Financing To Deposit Ratio (FDR) merupakan rasio yang digunakan untuk mengukur likuiditas suatu bank dalam membayar kembali penarikan dan yang dilakukan deposan dengan mengandalkan pembiayaan yang diberikan sebagai sumber likuiditasnya, yaitu dengan cara membagi jumlah pembiayaan diberikan oleh bank terhadap jumlah Dana Pihak Ketiga (DPK) (Suryani,2011:59). Dalam penelitian data FDR yang digunakan yaitu data bulanan yang dinyatakan dalam satuan persen, pada periode Januari 2009 sampai dengan Desember 2015 yang diperoleh dari Statistik Perbankan Syariah (SPS).

2. Variabel Dependen

Sertifikat Bank Indonesia Syariah (SBIS) adalah surat berharga berdasarkan prinsip syariah berjangka waktu pendek dalam mata vang rupiah yang diterbitkan oleh Bank Indonesia. Data yang digunakan dalam penelitian ini merupakan volume dana yang ditempatkan pada SBIS bulanan yang dinyatalan dalam satuan miliar pada periode Januari 2009 sampai dengan Desember 2015 yang diperoleh dari Statistik Perbankan Syariah (SPS).

\section{Jenis dan Sumber Data}

Jenis data yang digunakan dalam penelitian ini adalah data sekunder berupa data timeseries. Data sekunder dalam penelitian ini berasal dari pihak lain selain peneliti. Data sekunder yang digunakan dalam penelitian ini berasal dari laporan historis yang telah disusun dan dipublikasikan oleh bank Indonesia 
Supriono, et al/Jurnal Ekonomi Syariah Teori dan Terapan Vol. 4 No. 7 Juli 2017: 531-546; ANALISIS PENGARUH FINANCING TO DEPOSIT RATIO (FDR) TERHADAP PENEMPATAN DANA PADA SBIS BANK SYARIAH DI INDONESIA

yang diperoleh dari website resminya www.bi.go.id. Data yang digunakan dalam penelitian ini berupa data bulanan yang memiliki rentang waktu antara tahun 2009 sampai dengan tahun 2015.

\section{Populasi dan Sampel}

Populasi dalam penelitian ini adalah semua perbankan syariah yang ada atau industri perbankan syariah di Indonesia. Untuk pemilihan sampel, metode yang digunakan adalah metode sampel jenuh, yaitu seluruh populasi digunakan sebagai sampel. Berdasarkan metode pemilihan sampel yang dipilih, maka sampel dari penelitian ini adalah seluruh bank syariah yang ada di Indonesia.

\section{Prosedur Pengumpulan Data}

Jenis data yang digunakan dalam penelitian ini adalah jenis data sekunder yang bersifat times series dengan perhitungan bulanan (monthly) dengan jangka waktu Januari 2009 sampai Desember 2015. Data yang digunakan dalam penelitian ini diperoleh dari berbagai sumber diantaranya Statistik Perbankan Syariah (SPS) yang dipublikasikan oleh Bank Indonesia setiap bulan dan untuk melengkapi penjelasan dalam penelitian ini, maka data juga diperoleh dari beberapa jurnal serta literature terkait.

\section{Tekhnik Analisis}

Tekhnik analisis yang digunakan dalam penelitian ini adalah regresi linear sederhana dengan time series. Tekhnik analisis ini dipakai untuk memperoleh informasi ada atau tidak pengaruh Financing to Deposit Ratio (FDR) terhadap penempatan dana pada SBIS bank syariah di Indonesia. Adapun alat analisis yang digunakan adalah SPSS.

\section{HASIL DAN PEMBAHASAN}

Penelitian ini merupakan penelitian yang ruang lingkupnya adalah industri perbankan syariah di Indonesia dengan jumlah sampel Financing to Deposit Ratio (FDR) dan penempatan dana pada SBIS sebanyak 84 sampel. Sebelum analisis regresi dilakukan, berikut adalah tampilan nilai rata-rata indicator dari setiap observasi:

Tabel 2.

Descriptive Statistics

\begin{tabular}{|c|c|c|c|c|}
\hline Variabel & N & Minimum & Maksimum & Mean \\
\hline FDR & $\$ 4$ & 87,27 & 104,33 & 96,51 \\
\hline Imbalan SBIS & $\$ 4$ & 3,82 & 10,00 & 6,43 \\
\hline Penempatan pada SBIS & 84 & 2,34 & 9,15 & 4,31 \\
\hline
\end{tabular}

Sumber: Hasil Pengolahan data

Selisih antara nilai maksimum dan minimum FDR yaitu sebesar 17,56\% menunjukan keadaan yang cukup stabil, sebab nilai dari FDR tersebut cukup tinggi. Pada penempatan dana pada SBIS maksimum 10.663.000.000 dan maksimum dan minimum yaitu 1.253 .000 .000 perbedaan ini mengindikasikan bahwa dana yang ditempatkan pada SBIS berfluktuatif.

\section{Uji Syarat Regresi}

\section{Uji Normalitas}

"Uji normalitas dilakukan untuk menguji apakah dalam sebuah regresi variabel independen, variabel dependen atau keduanya memiliki distribusi normal" (Hakim 2001:254). Data yang dikatakan berdistribusi normal setidaknya memiliki 30 $\operatorname{data}(N)$, maka penelitian ini sudah 
dikatakan melebihi karena teridiri dar dua variabel independen dengan jumlah $\mathrm{N}$ sebanyak 168. Normalitas dapat dideteksi dengan melihat pola grafik Normal Probability Plo (NPP). Syarat yang digunakan dalam Normal Probability Plot (NPP) adalah grafik normal ditunjukan dengan penyebaran titik-titik disekitar garis diagonal yang mengindikasikan model regresi memenuhi asumsi normalitas.

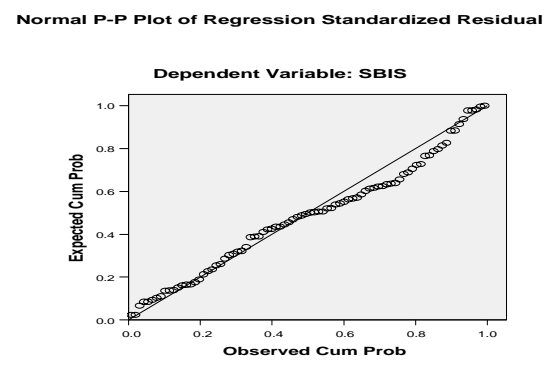

Sumber: Hasil uji SPSS 14. (data diolah). Gambar 2.

Normal P-P Plot of Regresion Standardized Residual

Berdasarkan gambar diatas menjelaskan bahwa data terdistribusi normal. Hal ini disimpulkan berdasarkan penyebaran titi-titik yang tersebar mengikuti garis diagonal.

\section{Uji linieritas}

Uji linieritas merupakan asumsi awal yang harus ada dalam model regresi linier. Uji linieritas pada regresi linier berganda dapat dilakukan menggunakan tabel anova dengan membandingkan nilai sig dengan tingkat alpha, dalam penelitian ini menggunakan tingkat alpha 0,05 (5\%). Apabila nilai Prob. $\mathrm{F}$ hitung lebih besar dari 0,05 maka dapat disimpulkan bahwa model memenuhi asumsi linieritas.
Tabel 3.

Tabel Anova

\begin{tabular}{|c|c|c|c|c|}
\hline Variatel & Flitures & $3 g$ & $d M$ & Ketengran \\
\hline SBISPDR & 12742 & $0,0,1$ & 0,05 & 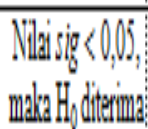 \\
\hline
\end{tabular}

Sumber: Hasil uji SPSS 14. (data diolah).

Berdasarkan Tabel diatas telihat bahwa Prob. F hitung 0,001 yang mana niali ini lebih besar dari 0,05 maka sesuai dengan syarat uji linieritas yang telah dijelaskan maka dapat disimpulkan bahwa model regresi ini memenuhi asumsi linieritas.

\section{Analisis Regresi sederhana}

Analisis regresi linier merupakan model analisis untuk mengetahui pengaruh variabel independen FDR terhadap variabel dependen penempatan dana perbankan syariah pada SBIS. Persamaan regresi linier dalam penelitian ini diperoleh melalui hasil uji SPSS 14. Berikut hasil pengolahannya.

Tabel 4.

Analisis Regresi sederhana

\begin{tabular}{|c|c|c|}
\hline Variabel & Koefisien (B) & Keterangan \\
\hline Konstanta & 21167,812 & $\begin{array}{c}\text { Merupakan } \\
\text { intersep }\end{array}$ \\
\hline FDR & $-167,389$ & $\begin{array}{c}\text { Bernilai } \\
\text { negative }\end{array}$ \\
\hline
\end{tabular}

Sumber: Hasil uji SPSS 14. (data diolah).

Berdasarkan nilai $\beta$ pada Tabel 4 di atas, maka persamaan untuk regresi linier 
sederhana dalam penelitian ini dapat ditulis sebagai berikut:

$Y=2116,812-167,389$ (FDR)

a. Nilai konstanta sebesar 21167,812 menunjukan apabila variabel FDR besarnya nol atau konstan, maka nilai penempatan dana perbankan syariah pada SBIS adalah sebesar 21167,812 .

b. Koefisien regresi FDR sebesar - 167,389 memiliki koefisien hubungan yang tidak searah dengan penempatan dana perbankan syariah SBIS. Setiap kenaikan satu satuan dari FDR, menyebabkan penurunan penempatan dana pada SBIS sebesar 167,389. Begitu pula sebaliknya, setiap penurunan sebesar satu satuan dari FDR, menyebakan kenaikan penempatan dana pada SBIS dengan asumsi bahwa variabel lain adalah konstan.

\section{Analisis Koefisien Determinasi}

Analisis koefisien determinasi dilakukan untuk mengukur seberapa jauh kemampuan variabel bebas dalam menjelaskan variabel dependennya. Nilai koefisien determinasi yang mendekati 1 maka variabel-variabel bebas memberikan hampir semua informasi yang dibutuhkan untuk memprediksi variasi variabel terikat. Berikut adalah hasil dari koefisien determinasi dari hasil ananlisis data:

Tabel 5.

Hasil Koefisien Determinasi

\begin{tabular}{|c|c|c|}
\hline Model & R-Square & $\begin{array}{c}\text { Adjusted R- } \\
\text { Square }\end{array}$ \\
\hline
\end{tabular}

\begin{tabular}{|c|c|c|}
\hline Model & 0,353 & 0,125 \\
\hline
\end{tabular}

Sumber: Hasil uji SPSS 14. (data diolah). Hasil regresi pada Tabel 5 diatas menunjukan nilai koefien determinasi $\left(R^{2}\right)$ adalah 0,353 atau $35 \%$ artinya bahwa variabel independen Financing To Deposit ratio (FDR)) mampu menjelaskan variabell dependen penempatan dana perbankan syariah pada Sertifikat Bank Indonesia Syariah (SBIS) sebesar 35\% dan sisanya $65 \%$ dijelaskan variabel lain yang tidak dibahas pada penelitian ini.

\section{Pengaruh Financing to Deposit Ratio (FDR)} Terhadap Penempatan Dana Pada SBIS

Berdasarkan hasil pengolahan data dapat Hasil pengujian regresi variabel Financing To Deposit Ratio diperoleh bahwa Financing To Deposit Ratio berpengaruh signifikan terhadap penempatan dana perbankan syariah pada SBIS. Hal ini dibuktikan dengan nilai prob. † hitung sebesar 0,000 yang mana nilai ini lebih kecil dari derajat kesalah 0,05. Variabel Financing To Deposit Ratio mempunyai koefisien $\quad-167,389$ ini menunjukan adanya hubungan yang tidak searah dengan dengan penempatan dana perbankan syariah pada SBIS. Kenaikan pada jumlah Fdr maka akan menyebabkan penurunan pada dana yang ditempatkan pada SBIS. Pengaruh yang signifikan ini disebabkan adanya peraturan dari Bank Indonesia bahwa perbankan boleh menempatkan dananya pada SBIS atau SBI lbank konvensional) setelah mencapai nilai FDR tertentu yang telah ditetapkan. Selain itu sifat ekonomi islam yang selalu menyentuh 
sektor riil seperti dikatakan oleh Nadeem dan Haque (1998) dalam Wibowo dan Widodo (2005:9) di sebutkan bahwa in Islamic system all rates of return in the financial sector are determined by activities in the real sector. Hal inilah yang menjadi identitas sistem ekonomi islam, penentuan imbalhasil yang didasarkan sektor riil memberikan dua efek yaitu pertama, kesehatan bank akan lebih terjaga hal ini dibuktikan dengan ketahanan bank syariah pada krisi 1998. Kemudian efek yang kedua dengan identitas sistem ekonomi islam yang mengutamakan sektor riil adalah pertumbuhan ekonomi yang mana tercermin melalui PDB yang tinggi dan terciptanya lapangan kerja.

Hasil tersebut menunjukan bahwa pertumbuhan penempatan dana pada Sertifikat Bank Indonesia Syariah sangat dipengaruhi oleh Financing To Deposit Ratio. Ketika rasio FDR rendah, hal ini mengindikasikan bank syariah mengalami masalah dalam penyaluran dananya melalui pembiayaan, sehingga banyak dana yang menganggur (idle). Akan tetapi berbeda jika rasio FDR tinggi hal ini mengindikasikan bahwa resiko pembiayaan rendah yang artinya bahwa bank syariah lebih banyak memutar dananya pada pembiayaan, sehingga hal ini berdampak negatif pada penempatan dana pada SBIS.

Hasil penelitian ini sejalan dengan penelitian yang dilakukan oleh $\mathrm{Al}$ Ma'rifatul A'la (2014) yang menyatakan bahwa:
"FDR berpengaruh negatif signifikan pada penempatan dana pada Sertifikat Bank Indonesia Syariah (SBIS) pada periode Januari 2009 sampai Oktober 2013".

Penempatan dana pada SBIS dilakukan jika ada sisa dana yang tidak dapat dialokasikan pada sektor pembiayaan yang merupakan sektor utama dalam perbankan syariah, maka bank syariah akan mengalokasikan dana mereka pada surat-surat berharga dengan tujuan agar tidak idle fund (A'la,2014: 602). Arifin ( 2006:53) menyatakan bahwa:

"porsi terbesar kedua dari fungsi penggunaan dana bank adalah investasi pada surat-surat berharga. Penempatan dana pada SBIS ini juga dilakukan perbankan syariah dengan tujuan untuk mejaga likuiditas bank syariah agar tetap stabil. "

Hasil penelitian ini juga sejalan dengan penelitian yang dilakukan oleh Uhudiah (2012) dari penelitian yang dilakukan juga didapatkan kesimpulan bahwa FDR berpengaruh negatif signifikan terhadap penempatan dana perbankan syariah pada SBIS.

Adanya resiko likuiditas yang sewaktu-waktu bisa terjadi pada perbankan syariah, maka perbankan syariah harus menjaga likuiditasnya dengan menempatkan dananya pada instrumen likuiditas. Penempatan pada instrumen likuiditas ini nilainya berbanding terbalik dengan dana yang dialokasikan pada pembiayaan, jika perbankan syariah mengalokasikan danaya pada pembiayaan lebih tinggi maka secara otomatis dana yang ditempatkan pada instumen likuiditas semakin kecil. 
Penempatan dana pada Sertifikat Bank Indonesia Syariah (SBIS) tidak hanya sebagai instrumen likuiditas tetapi juga sebagai instrumen investasi. Ismail dalam A'la (2011:39) menyatakan bahwa ;

"Fungsi utama bank syariah adalah menyalurkan dana kepada masyarakat yang membutuhkan dana dari pihak bank, maka prioritas bank syariah adalah pada sektor pembiayaan".

Hal ini mengindikasikan terdapat hubungan yang berbanding terbalik, ketika terjadi peningkatan pada FDR bank syariah maka akan terjadi penurunan penempatan dana bank syariah pada SBIS. hubungan yang berlawanan ini sesuai dengan konsep kebijakan moneter yang dilakukan oleh bank sentral. Kebijakan moneter yang dilakukan oleh bank sentral bertujuan untuk mengendalikan jumlah vang beredar yang pada gilirannya akan mempengaruhi inflasi dan perekonomian.

Salah satu cermin dari efektifnya mekanisme transmisi kebijakan moneter melalui jalur pembiayaan bank syariah adalah kondisi perekonomian yang stabil (PDB riil yag tinggi). Tingginya PDB ini dapat mendorong bank syariah untuk lebih memberikan pembiayaan pada sektor riil dikarenakan resiko pembiayaan yang rendah. Sehingga membuat FDR bank syariah akan terus mengalami perkembangan dan membuat dana bank syariah tidak ada yang idle, sehingga bank syariah tidak perlu menempatkan dananya pada SBIS. Ketika terjadi inflasi dan perekonomian yang mengalami kelesuan atau perlambatan pertumbuhan perekonomian, hal ini tercermin dari rendahnya pembiayaan yang diberikan pada sektor riil. Selain itu, tingginya jumlah vang beredar yang megnarah pada kondisi inflasi ini membuat instabilitas pada sektor moneter. Untuk mengtasi hal ini, maka bank sentral selaku otorias moneter mengambil kebijakan dengan mengeluarkan atau menerbitkan instrumen moneter pada operasi pasar terbuka berupa SBIS. sehingga dengan menerbitkan SBIS ini akan mengurangi jumlah vang beredar di masyarakat dan bank termasuk bank syariah akan menurun. Sehingga membatasi kemampuan bank syariah dalam memberikan pembiayaan pada sektor riil. Maka, FDR bank syariah akan mengalmi penurunan.

Dari sudut pandang syariah, penempatan dana pada SBIS oleh bank syariah telah sesuai dengan tuntunan syariah yang mewajibkan segala hal yang digunakan oleh bank syariah sebagai alat untuk menjalankan operasionalnya harus sesuai dengan prinsip syariah. Hal ini sesuai sabda Nabi SAW mengenai prinsip bermuamalah yang artinya:

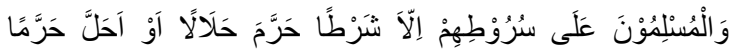

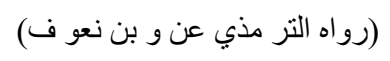

Artinya: "Kaum muslimin terikat dengan syarat-syarat yang mereka buat kecuali syarat yang mengaharamkan yang halal atau menghalalkan yang haram". (HR.Tirmidzi dari 'Amr bin 'Auf)

Hadist ini menjelaskan bahwa

segala kesepakatan yang dibuat dalam bermuamalah yang dilakukan oleh perorangan atau lembaga akan mengikat kedua belah pihak yang 
berkesepakatan, sehingga apa yang telah menjadi kesepakatan harus dilaksanakan sesuai dengan isi perjanjian kesepakatan tersebut. Akan tetapi ada kesepakatan yang tidak harus dilaksanakan yaitu, kesepakatan yang melanggar syariah seperti mengharamkan yang halal dan menghalalkan yang haram. Adanya SBIS dengan akad ju'alah yang telah difatwakan oleh DSN-MUI menandakan bahwa instrumen ini telah sesuai syariah.

\section{SIMPULAN}

1. Pada penelitian ini sebagian hipotesis tidak terbukti. Hanya variabel Financing to Deposit Ratio yang memenuhi hipotesis penelitian.

2. Financing To Deposit Ratio (FDR) berpengaruh signifikan terhadap penempatan dana perbankan syariah pada Sertifikat Bank Indonesia Syariah (SBIS) periode Januari 2009Desember 2015.

\section{DAFTAR PUSTAKA}

A'la. Ma'rifatul. 2014. Pengaruh Financing to Deposit Ratio (FDR) Terhadap Return On Asset (ROA) Dengan Variabel Intervening Penempatan Dana Pada Perbankan Sertifikat Bank Indonesia Syariah (SBIS) pada Bank Syariah Di Indonesia. Skripsi tidak dipublikasikan. Surabaya.

Fakultas Ekonomi dan Bisnis Universitas Airlangga.

Anshori, Muslich dan Iswati. 2009. Metodologi Penelitian Kuantitatif. Surabaya: Airlangga University Press.

Arifin, Zainul. 2005. Dasar-dasar Manajemen Bank Syari'ah. Jakarta: Pustaka Alvabet. 2006.

Dasar-dasar

Manajemen Bank Syari'ah. Jakarta : Pustaka Alvabet.
Antonio, Muhammad Syafi'i. 2001. Bank Syari'ah dari Teori ke Praktik Yogyakarta : Gema Insani Press.

Bank Indonesia. Peraturan Bank Indonesia Nomor 10 Tahun 2008 tentang Sertifikan Bank Indonesia Syariah. Jakarta: Diperbanyak oleh Direktorat Perbankan Syariah.

Departemen Agama Rl.2005. Al-quran dan Terjemahannya. Bandung: Syaamil Cipta Madia.

Dendawijaya, Lukman. 2005. Manajemen Perbankan, Edisi Kedua, Cetakan Kedua. Bogor: Ghalia Indonesia.

Ginting,Ramlan dkk.2013. Kodifikasi Peraturan Bank Indonesia Likuiditas Rupiah Operasi Moneter, Operasi Moneter Syariah dan Sertifikat Bank Indonesia Syariah. Jakarta: PRES Bank Indonesia.

Gulo, Melva Vicensia. 2014. Wadiah VS Ju'alah Pada Sertifikat Bank Indonesia Syariah. Universitas Negeri Surabaya.

Hakim,Abdul. 2001. Statistik Deskriptif untuk Ekonomi dan Bisnis. Yogyakarta: Ekonosia.

Hapsari, Nadhifa Alim. 2013. Pengaruh Tingkat Imbalan Sertifikat Bank Indonesia Syariah (SBIS) Terhadap Tingkat Pembiayaan dan Profitabilitas Bank Umum Syariah di Indonesia. Skripsi tidak dipublikasikan. Surabaya Fakultas Ekonomi dan Bisnis Universitas Airlangga.

Hidayat, Muhammad,MBA. 2010. An Introduction to the Sharia Economic Pengantar Ekonomi Islam. Jakarta: Zikrul Hakim.

Indrianto dan Supomo. 2002. Metode Penelitian Bisnis untuk akuntasni dan Manajemen, Edisi pertama. Yogyakarta: BPFE.

Mankiw,N. Gregory.2007. Makroekonomi. Edisi Keenam. Jakarta: Erlangga.

Muhammad. 2002. Manajemen Bnak Syariah. Yogyakarta: UPP STIM YKPN. 2005. Manajemen Bnak Syariah. Yogyakarta: UPP STIM YKPN. .2009. Manajemen Bnak Syariah. Yogyakarta: UPP STIM YKPN.

Nazir,Moh. 2005. Metode Penelitian. Jakarta; Ghalia Indonesia.

Pohan, Aulia. 2008. Kerangka kebijakan moneter dan Implementasinya di Indonesia. Jakarta : PT. Raja Grafido Persada. 
Rivai,Veithzal dan Arviyan Arifin.2010. Islamic Banking Sebuah Teori, Konsep, dan Aplikasi. Jakarta: Bumi Aksara.

Tandeilin,Eduardus. 2001. Portofolio Dan Investasi Teori dan Aplikasi. Yogyakarta:Kanisius.

Uhudiah.2012. Faktor-faktor Yng mempengaruhi penempatan dana pada perbankan syariah. Skripsi tidak dipublikasikan. Jakarta Fakultas Ekonomi UIN Syarif Hidayatullah.

Sugiyanto. 2001. Model analisis kuantitaif.Surakarta: Yuma Pustaka.

Suhartatik . 2014. Detreminan Financing to deposit ratio (FDR) Perbankan Syariah di Indonesia (2008-2012). Jurnal Ekonomi manajemen volume 1 No. 4 juli.

Soehartono,Irawan. 1999.Metode Penelitian Sosial suatu tehknik penelitian biciang kesejahteraan Sosial lainnya. Bandung: Remaja Rosda Karya.

Suryani.2011.Analisis Pengaruh Financing To Deposit Ratio (FDR) Terhadap Profitabilitas Perbankan Syariah Di Indonesia. Walisongo (1):59

Sumitro,Warkum. 2004. Asas-Asas Perbankan Islam Dan LembagaLembaga Terkait (Bamui, Takaful, Dan Pasar Modal Syariah IDi Indonesia. Jakarta: PT Raja Grafindo Persada.

Warjiyo, Perry dan Solikin. 2003. Kebijakan Moneter di Indonesia. Seri Kebanksentralan, Jakarta: Pusat Pendidikan dan Studi Kebanksentralan (PPSK), Bank Indonesia.

Wibowo,Edy dan Untung Hendi Widodo.2005. Mengapa Memilih Bank Syariah?. Bogor:Galia Indonesia.

Widarjono, Agus. 2010. Analisis statistika Multivariat Terapan. Yogyakarta: SYIM YKPN

Winarno, Wing Wahyu. 2009. Analisis Ekonometrika dan Statistika dengan Eviews. Edisi kedua. Yogyakarta: Sekolah Tinggi llmu Manajemen YKPN. 